\title{
A Survey on household Solid Waste Management and Assessment of Soil and Water quality of selected open Solid Waste Dumpsites in Kumaravayalur, Tiruchirappalli District, Tamil Nadu
}

\author{
Mohana Priya $\mathbf{S}^{\mathbf{1}}$, Jeline Rani $\mathbf{J}^{2}$ \\ ${ }^{1}$ PG - Botany, Bishop Heber college, Tiruchirappalli, Tamil Nadu \\ ${ }^{2}$ Assistant Professor, Botany, Bishop Heber college, Tiruchirappalli, Tami Nadu
}

\begin{abstract}
The current study focused on the measure of Public Awareness and Attitude on Solid Waste Management at Kumaravayalur Panchayat, Tiruchirappalli District, Tamil Nadu. The evaluation of soil quality and leachate around open solid waste dump also carried out. A pre tested and self-administered questionnaire was used for primary data collection covered 300 household which were selected randomly. $60 \%$ of the total waste collection was obtained from the kitchen. Nearly $16 \%$ wastes belong to non-biodegradable especially Plastic type. Out of 300 household, $67.83 \%$ used to prepare manure from the kitchen waste. Nearly $25 \%$ involved in the active participation for home composting is appreciable. The results also showed that $75 \%$ of the households were not aware of 3R's (Reduce, Reuse, Recycle). $75 \%$ of the households was satisfied with the existing Waste Management System. The assessment of the soil quality of six open solid waste dump sites were selected and the assessment of Soil quality based on the characteristics such as pH, EC, NPK content and the level of $\mathrm{Fe}, \mathrm{Mn}, \mathrm{Zn}$ and $\mathrm{Cu}$. The analysis of soil samples from the above locations showed that open solid waste dump at these sites had drastically modified the soil characteristics. Among the six landfill leachate samples analysis, few sites showed the increased level of Total Hardness, COD and Calcium indicated the influence of the Solid Waste.
\end{abstract}

Key Words: Solid Waste Management, Solid waste dumpsite, Public Awareness, Attitude

\section{INTRODUCTION}

Pollution has become a very significant yet serious issue in today's scenario. It has been there for a long time and cause various photochemical reactions in the region of atmosphere. Soil pollution represents the contamination of soil due to the presence of toxic substances. There are a few other pollutants causing significant damage apart from the afore mentioned ones such as solid wastes. Solid waste management is one of the significant problems looking towards by cities all over the world. This arises especially due to urbanization, industrialization, sub-standard urban planning and dearth of appropriate resources which contribute to the extensive amount of solid waste generation. This issue resulted in significant environmental, social and economic problems in the developing countries like India. Population growth and economic activities in and around the metropolis has resulted in a waste management crisis. The rise of mega-cities and per capita waste generation in Metropolis are the cause for the increased issues of solid wastes. The per capita waste generation is $0.21 \mathrm{~kg}$ per day in urban areas with a population of less than 0.1 million people while in areas with a people of more than 5 million people, it is $0.5 \mathrm{~kg}$ per day (Askariaunet al., 2004, Bavejaet al., 2000) The per capita of Municipal Solid Waste (MSW) generated is vary from $100 \mathrm{~g}$ to $500 \mathrm{~g}$ in small towns and large towns respectively (CPCB, 2000). Solid waste generation and dumping is a continually growing issue prevailing at global, regional and local levels. Organic and inorganic wastes generated by the various activities of the society and its improper disposal leads to impairment of the living environment at local and global level (Ramachandra, 2006). The lack of knowledge of Solid Waste Management and there is no specific approach to SWM. The integrated approach such as, Composting, Incineration and landfilling are the possible ways for the Solid Waste Management. Landfilling is the cheapest and easiest method of disposal (Lemaet al., 1988). Open dumping is one of the improper disposal mechanisms of Solid wastes. Due to that, degradation of organic wastes leads to the formation of stagnant water and it acts as a home place for the production of bacteria, mold and parasites. These pathogenic organisms formed due to the open dumping cause so many health hazards to the human beings. The parasites such as, Mosquitoes breed on the stagnant water and disseminating diseases such as, Malaria, Chikungunya and encephalitis to human kind. The open dumping is very common phenomenon in Kumaravayalur Village 


\section{DOI: 10.17148/IARJSET.2021.8872}

Panchayat. This study conducted to show the extent of pollution status in the soil and leachate nearby to solid waste dump sites. Therefore, this study attempts to understand the level of awareness and status of Solid Waste Management handled by Kumaravayalur Village households.

\section{Study Area}

\section{MATERIALS AND METHODS}

Kumara Vayalur is a small village/hamlet in Srirangam Taluk in Tiruchirappalli district of Tamil Nadu state, India. This village is located 9 kilometers away from the heart of Tiruchirappalli District. This village is very fame for its temple called VayalurMurugan. It is 357 kilometers away from Chennai and the local language is Tamil. It is served by the Mekkudi and Mutarasanallur railway stations, with the closest major railway station 8 kilometers away from Tiruchirappalli.

\section{Survey}

The Solid Waste Management (SWM) data was collected from the local people of Kumaravayalur village Panchayat by using a questionnaire. The Survey was conducted from February 2021 to March 2021. The questionnaire which contains two parts, the first part is about the details of the respondents and the second part contain the questions related with the Solid Waste Management of the Kumaravayalur Village Panchayat. A total of 300 household were randomly selected for the study. The questionnaire which contains 30 questions related with the measure of attitude on Solid Waste Management.The standard questionnaire of Public Awareness and Attitude on Solid Waste Management adapted by Vibhooti Narayan (2015) was followed in this survey.

\section{Data Analysis}

Data was analyzed using descriptive statistics such as percentage and frequency. Microsoft Excel spreadsheet was used to organize and analyze the data.

\section{Collection of Soil Samples}

The sample sites were selected by simple random sampling method. The soil samples were collected from the solid waste dump sites such as, Kumaravayalur (S1), Adavathur(S2), Kurinji Nagar (S3), Bharathi Nagar (S4), Chandrakasa Nagar (S5), Lakshmi Nagar (S6) byusing wooden ladles with gloves in hand. All the soil samples were drawn at $20 \mathrm{~cm}$ deep from each open solid waste dumpsites. The exact location of sampling was present at 5 meters away from the circumference of dumpsites. All the soil samples were collected by using polythene bags and labelled.

\section{Collection of landfill leachates}

From the selected sites as mentioned in the soil sample, the landfill leachates were collected at the same dump sites such as, L1, L2, L3, L4, L5 \& L6. The water samples collected from six different sites such as, Kumaravayalur (L1), Adavathur (L2), Kurinji Nagar (L3), Bharathi Nagar (L4), Chandrakasa Nagar (L5) and Lakshmi Nagar (L6). In order to compare the landfill leachate with the portable water, the drinking water sample was collected and used as control (C). The landfill leachates were collected by using disposable cups, moved at a depth of $10 \mathrm{~cm}$ in order to avoid the floating debris and transferred in to the 1 Liter Polythene water bottles with cloves in hand.

\section{Analytical Methods}

The standard procedure ofNigam and Mahendra (2014)was adapted for the analysis of Physico-chemical parameters of soil, such aspH, EC, N, P, K and trace elements.APHA (2005) was used for the measurement of pH, Total Hardness, Total Dissolved Solids (TDS), Calcium, Magnesium, Sodium, Potassium, BOD and COD of leachate water samples.

\section{Survey}

\section{RESULTS AND DISCUSSION}

In the current study, survey was conducted on awareness of Solid Waste Management at Kumaravayalur Panchayat, Tiruchirappalli District, Tamil Nadu. The findings of the present study revealed the perspective on disposal of solid waste and the awareness level of Solid Waste Management. Among 300 households, $60 \%$ of food waste is produced in the majority of householdsas seen in Figure 1. Only $43.33 \%$ do separate their household wastes into degradable and non-biodegradableas illustrated in Fig. 2. The most surprising aspect of the data is, $19.08 \%$ do not know how to separate the waste is shown in Fig. 3. A significant percentage of households (12.14\%) think that separation is not their job. $63.01 \%$ agreed that, it is not helpful when they think about waste separation. $2.31 \%$ households are not showing any interest by doing the separation due to lack of awareness. $98 \%$ of the respondents doesn't know about where and how the collected garbage is getting disposed from their areaas illustrated in Fig. 4. Regarding 3Rs i.e., Reduce, Reuse, and Recycle is the majority $(75.67 \%)$ of respondents reported that they don't know at all.Figure 5 shows, $45.33 \%$ of respondents recommended to increase the number of waste containers in each area. It indicates the lack of enough garbage pins in 
DOI: $10.17148 /$ IARJSET.2021.8872

each area and even though if they present, the size of the bins are not large enough to hold, all the solid waste dump for a long period of time.

\section{Physico-chemical Analysis of Soil Samples}

The result on the color of soil samples collected from various dumpsites showed Brown (S1 \& S2), Grey (S3 \& S4), Black (S5) and Red (S6) color. The recorded $\mathrm{pH}$ value in all the solid waste dumpsites showed $\mathrm{pH}$ value range between 8.45 to 8.88. the highest $\mathrm{pH} 8.88$ was recorded in Chandrakasa Nagar (S5) as seen in Fig. 6. It revealed that, soil samples belong to moderately alkaline category. Alkalinity of the soil may cause due to the solid wastes accumulated in the dump sites can change the nature of the soil. The EC values of soil observed in all solid waste dump sites ranges between 0.13 $\mathrm{ds} / \mathrm{m}$ to $0.33 \mathrm{ds} / \mathrm{m}$ indicates a significance presence of trace metal ions or ionizable materials in the dumpsite. The highest EC level of soil sample was measured as $0.33 \mathrm{dS} / \mathrm{m}$ in $\mathrm{S} 5$ is shown in Fig. 7.Among all the tested sites, highest nitrogen content was reported as $78.4 \mathrm{~kg} / \mathrm{ha}$ in $\mathrm{S} 6$ as seen in Fig. 8. Highest phosphorous estimated as $7.0 \mathrm{~kg} / \mathrm{ha}$ in S5and maximum potassium level ie., $142 \mathrm{~kg} / \mathrm{ha}$ was observed in S4as illustrated in Fig. 9 \& 10respectively. Among all the open solid waste dumpsites, S4, S5 and S6 showed the increased level of NPK content. Copper (Cu), Manganese (Mn) and Zinc (Zn) are considered as trace elements of potential soil contaminants. In Fig.13, the trace element concentration of copper was very low when compared with recommended standards $(1500 \mathrm{ppm})$ in all the solid waste dump sites (S1 to S6). Similarly, the concentration of Zinc also very less in all the dump sites $(0.86 \mathrm{ppm}$ to $1.03 \mathrm{ppm})$ which is comparably very less concentration with that of standard permissible level $(700 \mathrm{ppm}-1850 \mathrm{ppm})$ is shown in Fig. 12. The concentration of Manganese (Mn) in all the solid waste dumpsites (S1 to S6) showed the slight lower level (3.01 ppm to $3.21 \mathrm{ppm}$, when compared with that of standard Level (5-200 ppm) as given in Fig. 11, The concentration of Iron was also same in all the solid waste dump sites ranges from $5.02 \mathrm{ppm}$ to $5.61 \mathrm{ppm}$ is shown in Fig. 10.

\section{Landfill leachate water Sample Analysis at various dump sites}

The $\mathrm{pH}$ of the leachate water samples L2 to L6 fall in the ranges between 8.00 to 8.66 fall under slightly alkaline pH is shown in Fig. 14.These results reflect those of Przydatek \& Wlodzimierz, 2019, Mekonnen et al., 2020 who also found the alkaline leachates in the solid dumpsites. According to Manivasagam (1987), the water samples showing $\mathrm{pH}$ above 8 , contain carbonates with or without bicarbonate and they do not contain free carbonic acid. Fig. 15 shows, Total hardness of leachate water samples ranges from $230-655 \mathrm{mg} / \mathrm{L}$, which indicates that all the samples are belong to Hard type. Several factors are responsible for the hardness of water such as accumulation of salts from contact with soil, geological foundations and direct pollution by the accumulation of solid wastes. It is mainly the calcium ions which causes hardness (Trivedy and goel, 1986). The results revealed, the content of calcium was, $102 \mathrm{mg} / \mathrm{l}, 46.09 \mathrm{mg} / 1,132.26 \mathrm{mg} / \mathrm{l}, 150.30$ $\mathrm{mg} / \mathrm{l}, 60.12 \mathrm{mg} / \mathrm{l}, 208.15 \mathrm{mg} / \mathrm{l}$. L1, L3, L4 and L6 dumpsites leachate samples showed higher calcium content as seen in Fig. 16. The permissible level of calcium in drinking water is $75 \mathrm{mg} / \mathrm{l}$ according to WHO. This may due to the inclusion of high amount of $\mathrm{CaCo3}$. All the solid waste dump site leachate water samples have shown the low Magnesium values ranges between $11.02 \mathrm{mg} / 1$ to $97.20 \mathrm{mg} / \mathrm{l}$ as illustrated inFig. 17. This may due to mineral leaching process. Total Dissolved Solids were estimated and the results revealed that total solids present in the tested leachate water samples ranges between $721 \mathrm{mg} / \mathrm{l}$ to $375 \mathrm{mg} / \mathrm{l}$ as seen in Fig.18. A high content of Dissolved solids, elevates the density of water, influences osmoregulation of fresh water organisms, reduces solubility of gases (like $\mathrm{O} 2$ ). The most striking result to emerge from the data is that, all the solid waste dump site leachate samples have shown the low BOD values ranges between $3.08-7.34 \mathrm{mg} / \mathrm{L}$ is shown in Fig. 21. These results indicated that these waters are heavily contaminated by the action of microorganisms. Figure 22 shows, L1 and L2 dumpsites showed higher concentration of COD such as, 172.00 and $200.00 \mathrm{mg} / \mathrm{L}$ respectively. and low COD value when compared with Control site (40.00 mg/l). It is due to the availability of oxygen for the oxidation is very low. When compared with WHO standards, most of the leachate water samples have shown the higher values of $\mathrm{pH}$, Total harness, Calcium, Magnesium, TDS, Sodium, Potassium, BOD \& COD.

Fig. 1 Types of Waste Generated by Households

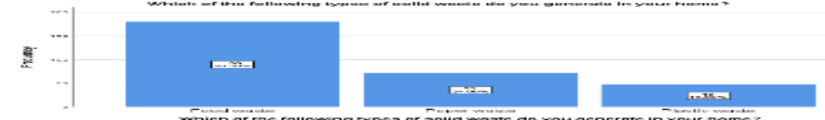

Fig. 2 Separation of Solid waste as Composable and decomposable

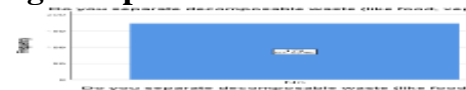

Fig. 3 Reasons for not separating biodegradables from non- biodegradables

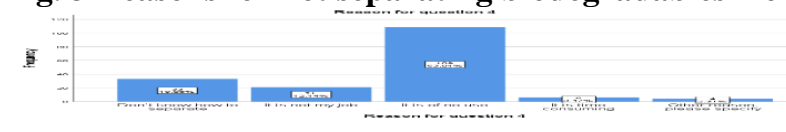


International Advanced Research Journal in Science, Engineering and Technology

Vol. 8, Issue 8, August 2021

DOI: $10.17148 /$ IARJSET.2021.8872

Fig. 4 Awareness of Household on SWM

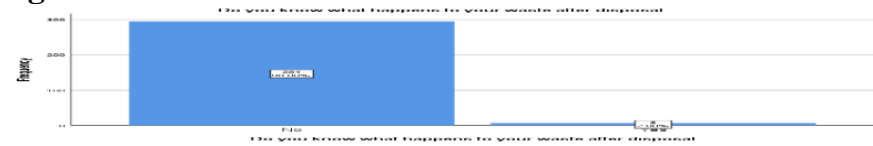

Fig.5
An
increase
in number
of

waste

containers

in each

area$$
\text { axtos }
$$

$\ldots$

Physico-chemical Analysis of Soil and water Sample Analysis at various dump sites

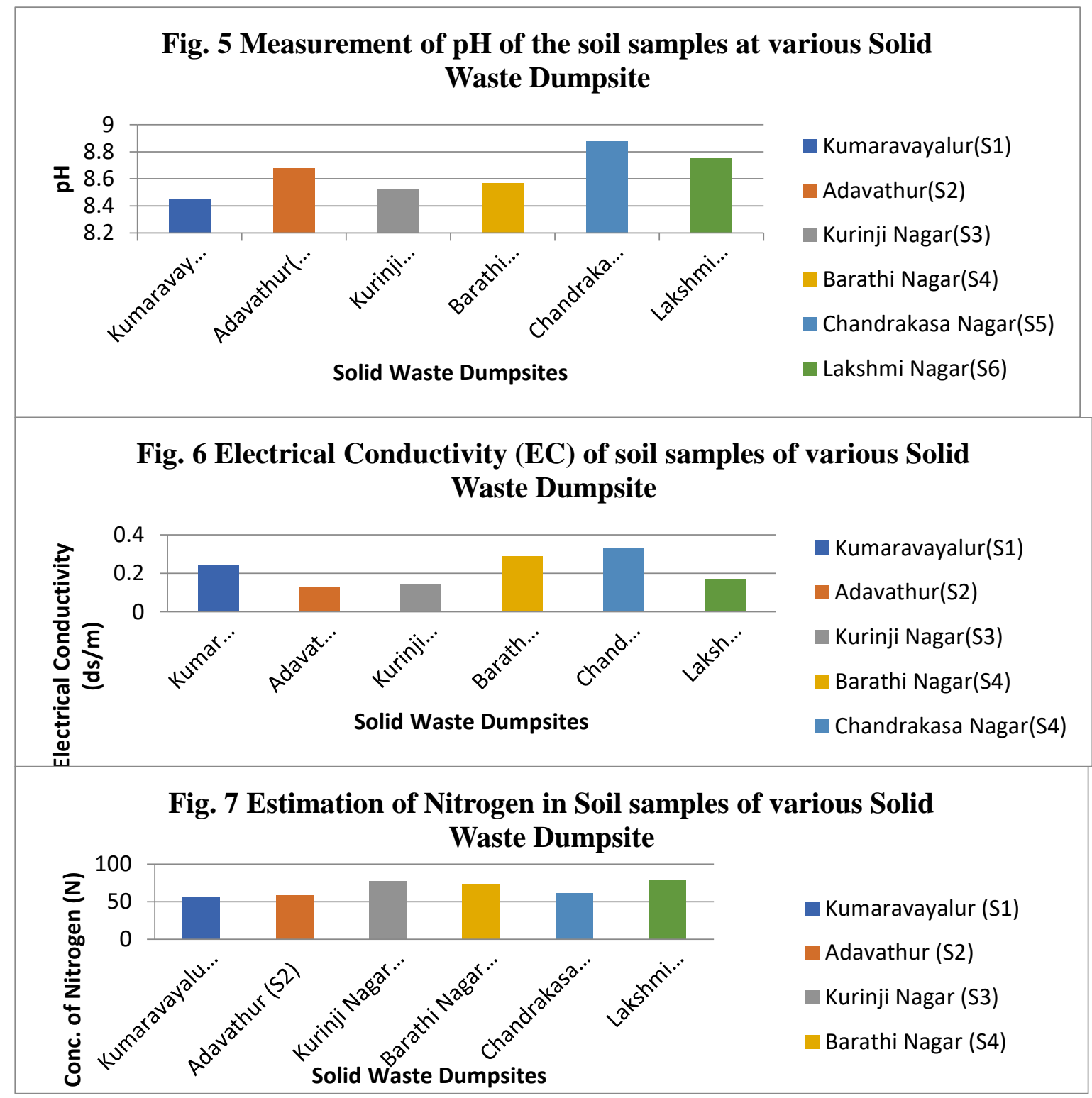


International Advanced Research Journal in Science, Engineering and Technology

Vol. 8, Issue 8, August 2021

DOI: $10.17148 /$ IARJSET.2021.8872
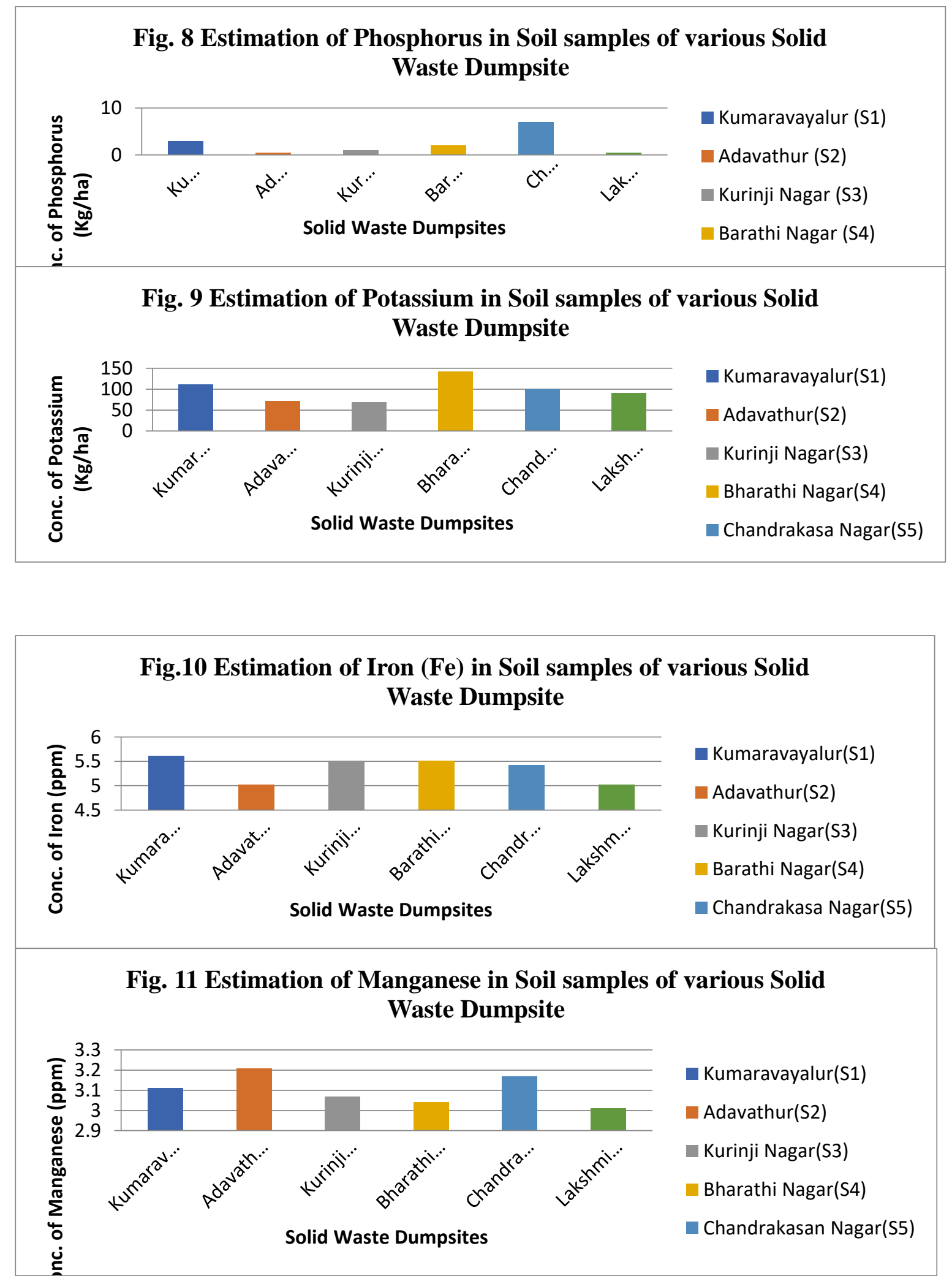
International Advanced Research Journal in Science, Engineering and Technology

Vol. 8, Issue 8, August 2021

DOI: 10.17148/IARJSET.2021.8872

Fig. 12 Estimation of Zinc in Soil samples of various Solid Waste Dumpsite

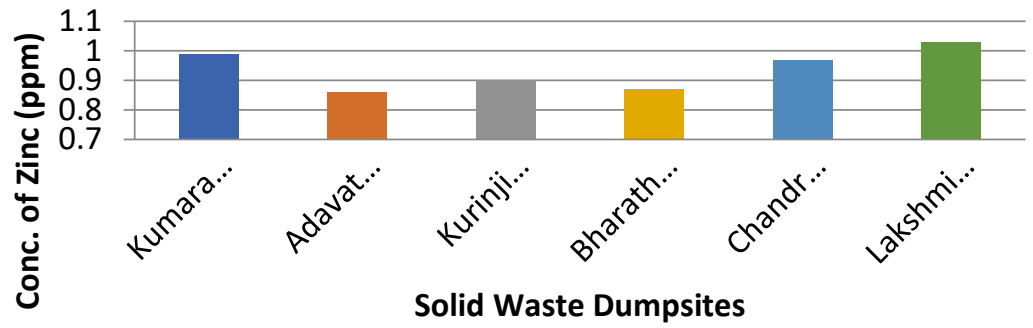

- Kumaravayalur(S1)

Adavathur(S2)

Kurinji Nagar(S3)

Bharathi Nagar(S4)

- Chandrakasa Nagar(S5)

Fig. 13 Estimation of Copper in Soil samples of various Solid Waste Dumpsite

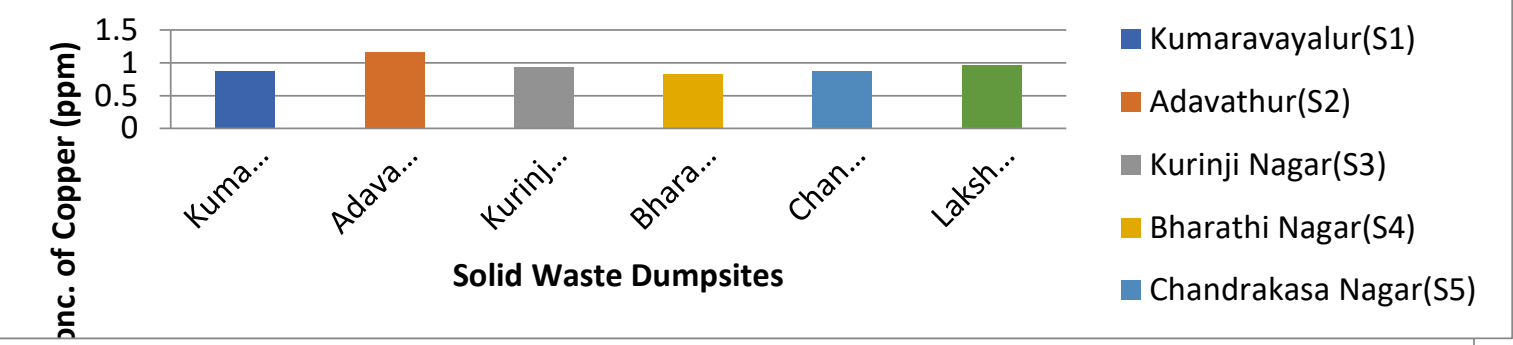

Fig. 14 Measurement of $\mathrm{pH}$ of the Land fill Leachates

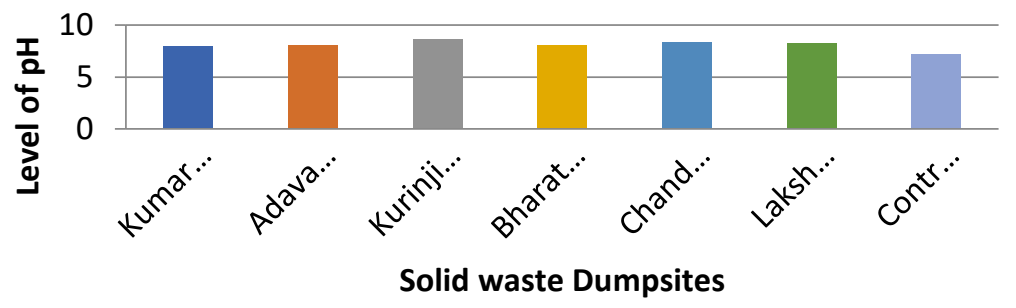

- Kumaravayalur (L1)

Adavathur (L2)

- Kurinji Nagar (L3)

Bharathi Nagar (L4)

- Chandrakasa Nagar (L5)

Fig. 15 Analysis of Total Hardness of the Landfill Leachates

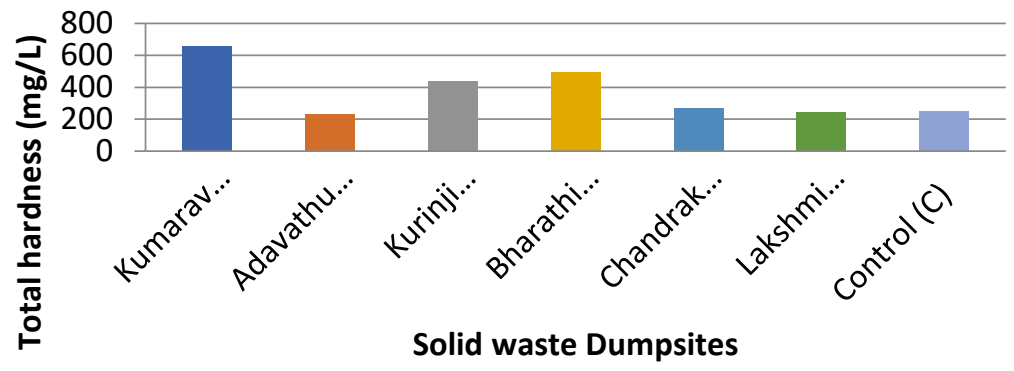

- Kumaravayalur (L1)

- Adavathur (L2)

Kurinji Nagar(L3)

Bharathi Nagar (L4)

- Chandrakasa Nagar (L5)

- Lakshmi Nagar (L6) 
International Advanced Research Journal in Science, Engineering and Technology

Vol. 8, Issue 8, August 2021

DOI: $10.17148 /$ IARJSET.2021.8872
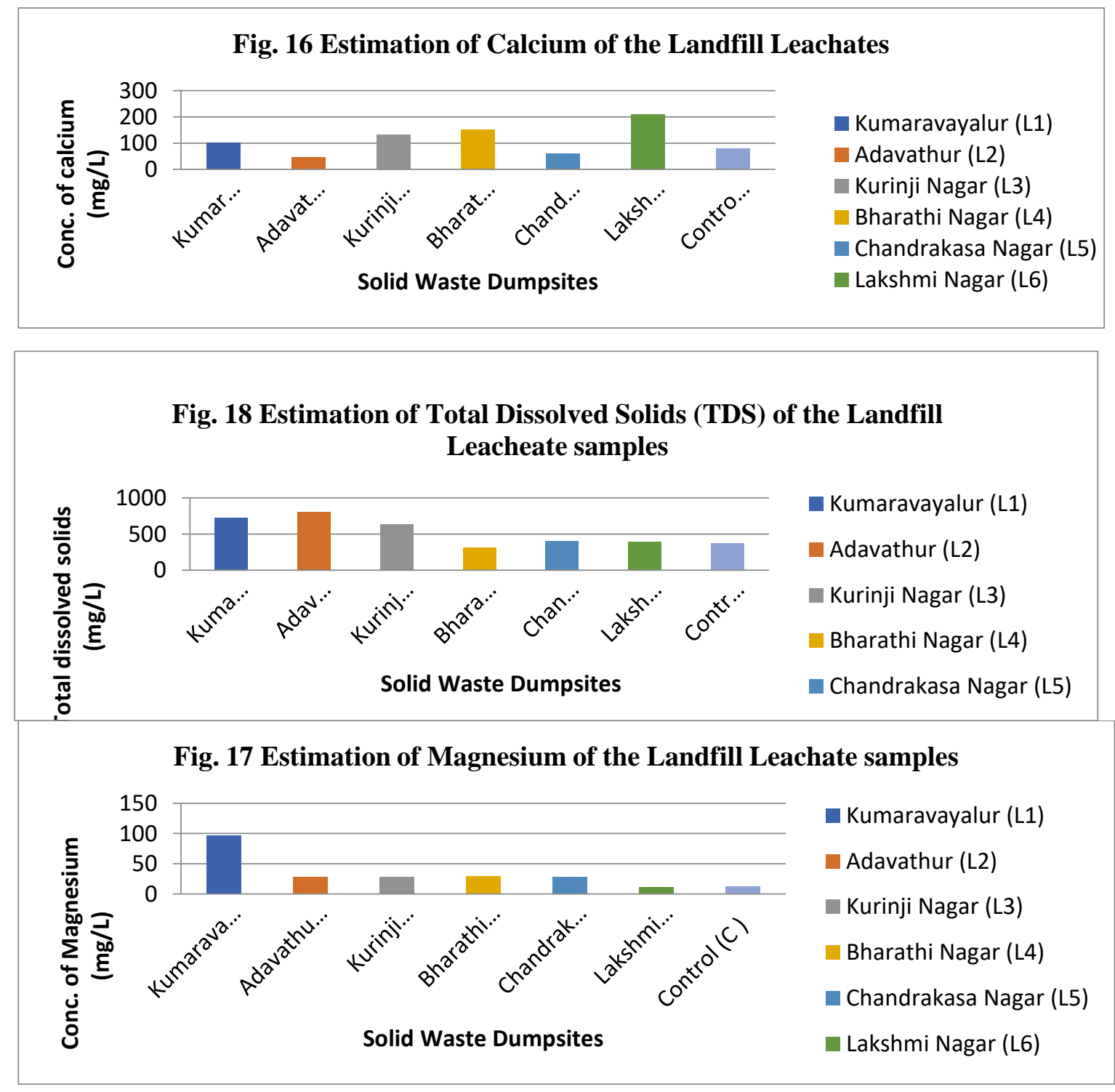

Fig. 19 Estimation of sodium of landfill leachate samples

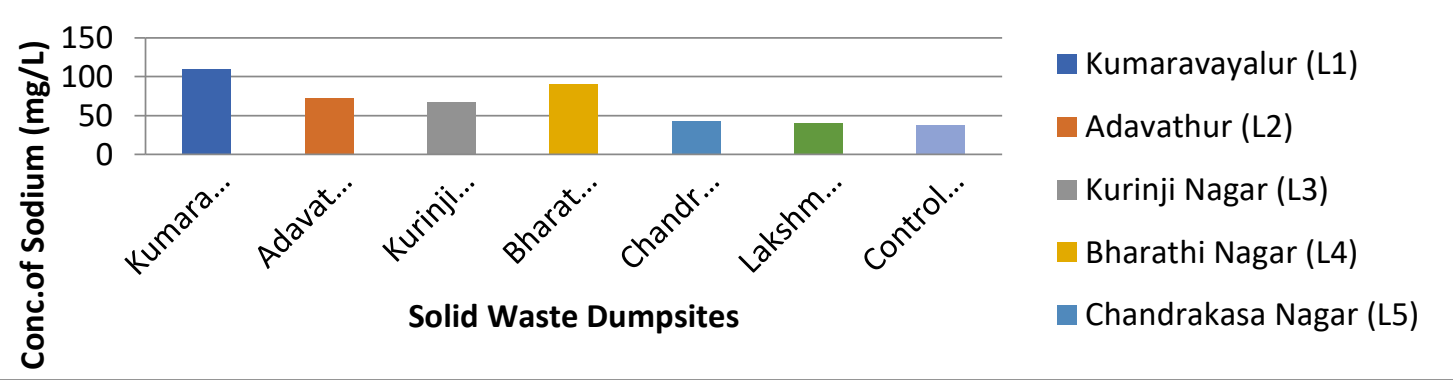


DOI: $10.17148 /$ IARJSET.2021.8872

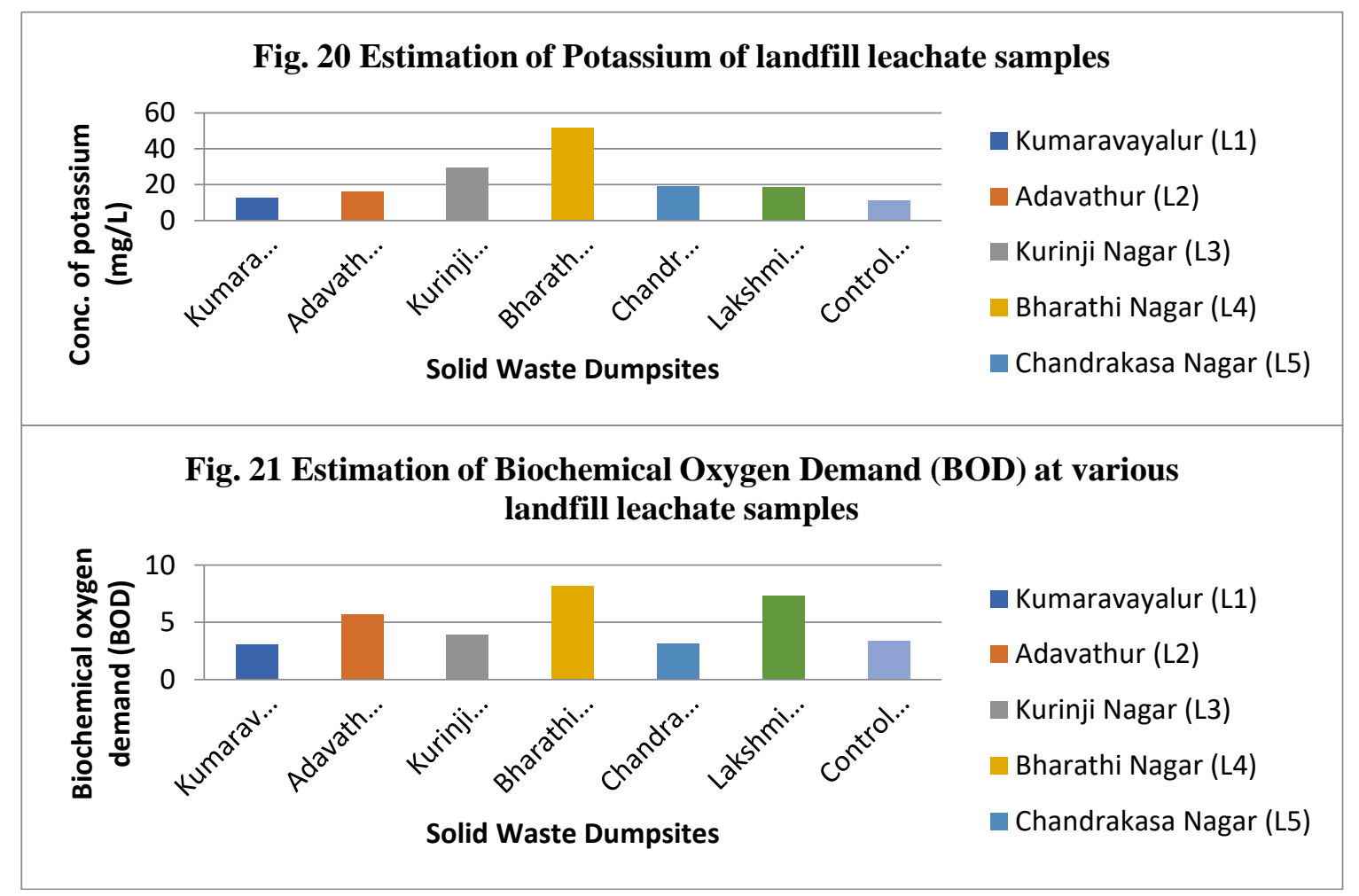

Fig. 22 Estimation of Chemical Oxygen Demand (COD) at various landfill leachate samples

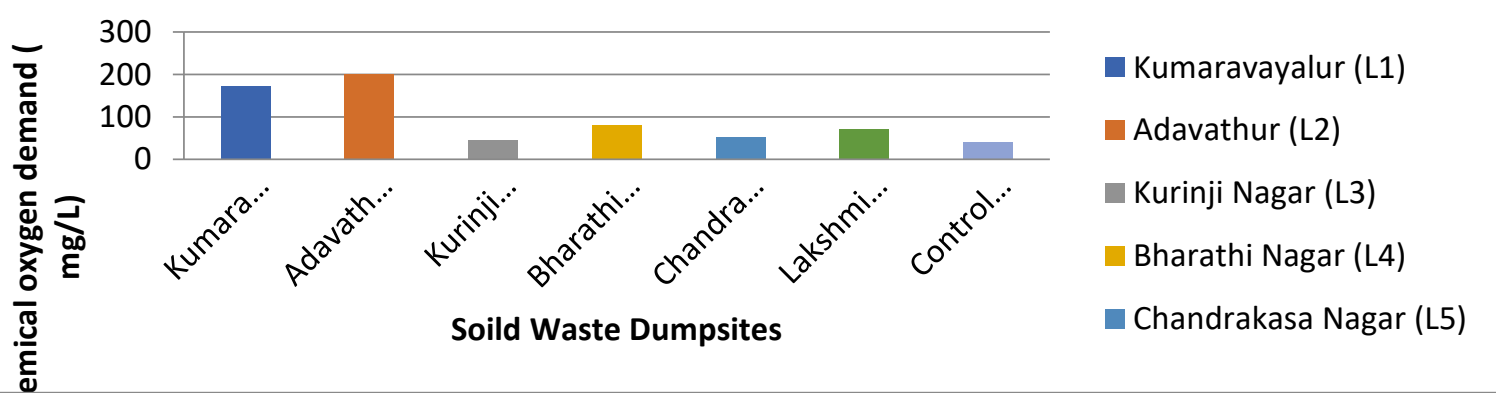

\section{CONCLUSION}

The findings of the present study revealed the perspective on Public Awareness and Attitude on Solid Waste Management and the quality of soil and leachate water samples collected at open solid waste dumpsites at Kumaravayalur, Tiruchirappalli. This study identified the lower awareness level of Solid Waste Management among Kumaravayalur households. The survey result has shown that, half of the households are not separating the wastes due to lack of interest and awareness. One of the more significant findings to emerge from the study is that, majority of the households (75\%) didn't know about 3R's (Reduce, Reuse \& Recycle). The solid wastes on the dump sites had shown a negative impact on the physico-chemical characteristics of soil and leachate water samples. The indiscriminate disposal of solid wastes may cause the exceeding level of NPK content and trace elements than the permissible level recommended by WHO. Overall, this study strengthens the idea that, the creation of awareness regarding the Solid Waste Management and 3R's should be given to the households of Kumaravayalur.

\section{REFERENCES}

1. Askarian, M., Vakili, M. and Kabir, G., 2004. Results of a hospital waste survey in private hospitals in Fars province, Iran. Waste management, 24(4), pp.347-352.

2. Beutler, M., Wiltshire, K.H., Meyer, B., Moldaenke, C., Luring, C., Meyerhofer, M. and Hansen, U.P., 2014.

3. APHA (2005), Standard Methods for the Examination of Water and Wastewater, Washington DC: American Public Health Association. Ahmad, SR, 


\title{
International Advanced Research Journal in Science, Engineering and Technology
}

\author{
Vol. 8, Issue 8, August 2021
}

\section{DOI: 10.17148/IARJSET.2021.8872}

and DM Reynolds (1999), Monitoring of water quality using fluorescence technique: Prospect of on-line process control, Water Research, 33 (9), 20692074. Arar, EJ and GB Collins (1997), In vitro determination of chlorophyll a and pheophytin a in. Dissolved Oxygen Dynamics and Modeling-A Case Study in A Subtropical Shallow Lake, 217(1-2), p.95.

4. Central Pollution Control Board., 2000. Management of Municipal Solid Waste, Delhi, Central Pollution Control Board

5. Lema, G., Mesfun, M.G., Eshete, A. and Abdeta, G., 2019. Assessment of status of solid waste management in Asella town, Ethiopia. BMC public health, 19(1), pp.1-7.

6. Manivasakam, N., 1987. Industrial Effluents Origin, Characteristics. Effects Analysis and Treatment, Sakthi Publication, Coimbatore, India.

7. Mekonnen, B., Haddis, A. and Zeine, W., 2020. Assessment of the Effect of Solid Waste Dump Site on Surrounding Soil and River Water Quality in Tepi Town, Southwest Ethiopia. Journal of Environmental and Public Health, 2020.

8. Narayan, V. and Sharma, A., 2016. Public Private Partnership for Solid Waste Management: A Case Study of Varanasi City. Dynamics of Public Administration, 33(1), pp.83-101.

9. Nigam, G.K., Pandey, V.K., Tripathi, M.P. and Sinha, J., 2014. Assessment of macro and micro nutrients of soil in a small Agricultural watershed. International Journal of ChemTech Research, 6(7), pp.3658-3664.

10. Przydatek, G. and Kanownik, W., 2019. Impact of small municipal solid waste landfill on groundwater quality. Environmental monitoring and assessment, 191(3), pp.1-14.

11. Ramachandran, T.V..2006. Management of Municipal Solid Waste, TERI press, The Energy and Resource Institute, Durbar Seth block, IHC Complex, Lodhi road, New Delhi pp-16-18.

12. Trivedy, R.K. and Goel, P.K., 1984. Chemical and biological methods for water pollution studies. Environmental publications.

13. HIMANSHU SEKHAR BEHERA; Bijoy kumar pany. "Soil properties of medium land rice (Oryza sativa L.) in inorganic nitrogenous fertilizers on fym combination in yield". International Research Journal on Advanced Science Hub, 3, Special Issue ICIES-2021 4S, 2021, 46-49. doi: 10.47392/irjash.2021.109

14. Karthikraj H; Kavinraja A S; Kishore Karthi; Sree Poornalinga K. "AgriGeek - A Mobile Application based on Smart Farming Hybrid Monitoring System". International Research Journal on Advanced Science Hub, 2, 6, 2020, 11-14. doi: 10.47392/irjash.2020.30

15. Kaaviya L. "Design, analysis and data management of open Drain/Sewer solid waste cleaning robot". International Research Journal on Advanced Science Hub, 2, Special Issue ICSTM 12S, 2020, 88-92. doi: 10.47392/irjash.2020.267

16.Ms.Anurekha G.S; K.Thirumalai Raja. "Experimental Study on Partial Replacement of Msand with Ground Granulated Blast Slag". International Research Journal on Advanced Science Hub, 2, 7, 2020, 60-66. doi: 10.47392/irjash.2020.66 